\title{
Incidence of congenital malformation in 2 major hospitals in Rivers state of Nigeria from 1990 to 2003
}

\author{
T.B. Ekanem, ${ }^{1}$ I.E. Bassey, ${ }^{7}$ O.E. Mesembe, ${ }^{1}$ M.A. Eluwa ${ }^{7}$ and M.B. Ekong ${ }^{1}$
}

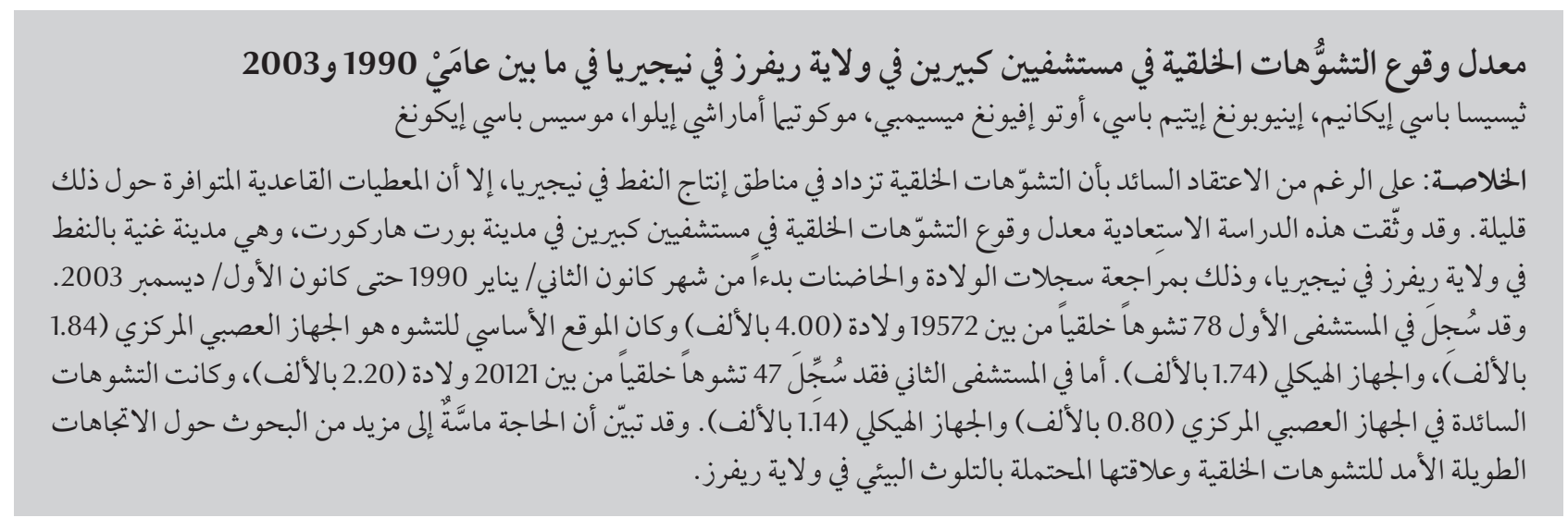

ABSTRACT Although congenital malformations are believed to be on the rise in the oil production areas of Nigeria, few baseline data are available. This retrospective study documented the incidence of congenital abnormalities in 2 major hospitals in Port Harcourt, an oil-rich city in Rivers state, Nigeria. Delivery and nursery records were reviewed from January 1990 to December 2003. In the first hospital 78 congenital anomalies were recorded out of 19572 births (4.00/1000), principally affecting the central nervous system (1.84/1000) and skeletal system (1.74/1000). In the second hospital, 47 congenital anomalies were recorded out of 20121 births (2.20/1000), with malformations of the central nervous system (0.80/1000) and skeletal system (1.14/1000) again predominating. More research is needed into long-term trends in congenital malformations and possible associations with environmental pollution in Rivers state.

Incidence des malformations congénitales dans deux grands hôpitaux de l'État de Rivers (Nigéria) de 1990 à 2003

RÉSUMÉ Les malformations congénitales seraient en augmentation dans les zones de production pétrolière au Nigéria, mais peu de données de référence sont disponibles. Cette étude rétrospective a recueilli des données sur l'incidence des anomalies congénitales dans deux grands hôpitaux de Port Harcourt, une riche cité pétrolière de l'État de Rivers (Nigéria). Les dossiers obstétricaux et pédiatriques de janvier 1990 à décembre 2003 ont été examinés. Dans le premier hôpital, sur 19572 naissances, 78 anomalies congénitales ont été enregistrées (soit 4,00 pour 1000) : elles affectaient principalement le système nerveux central (1,84 pour 1000) et le squelette (1,74 pour 1000). Dans le deuxième hôpital, 47 anomalies congénitales ont été enregistrées pour 20121 naissances (soit 2,20 pour1000) ; les malformations concernaient aussi majoritairement le système nerveux central ( 0,80 pour 1000) et le squelette (1,14 pour 1000). Des recherches supplémentaires sont nécessaires pour étudier les tendances à long terme des malformations congénitales et les associations possibles avec la pollution environnementale de l'État de Rivers.

${ }^{7}$ Department of Human Anatomy, Faculty of Basic Medical Sciences, University of Calabar, Calabar, Nigeria (Correspondence to M. Ekong: mbe_ flashpoint@yahoo.com).

Received: 29/09/09; accepted: 11/02/10 


\section{Introduction}

Congenitalmalformationsincludemorphological defects as well as abnormal behaviours, functions and chemistry noticed at birth or present from birth and becoming evident as the child gets older. They include defects of molecular structure giving rise to inborn errors of metabolism [1]. Congenital malformations often result in significant morbidity or even death of the infant [2].

Congenital malformations can be due to an abnormally shaped uterus [3], alterations in the genes (which could be autosomal or sex-linked) [4,5], irradiation $[4,5]$, smoking or drinking of alcohol by the mother [6], infections, poor nutritional status or medication use by the mother during pregnancy $[5,7,8]$. Some of these malformations result in heart disease and nervous system deformities including mental retardation. Others include ocular defects, infertility, skeletal deformities and spontaneous abortion in those infants who cannot survive [7].

Manning et al. stated that the frequency of major congenital malformations detected at birth varies from $1 \%-1.17 \%$, increasing to $2 \%-3 \%$ at about 5 years of age [9]. The incidence of congenital malformations varies depending on racial/ethnic and geographical factors. Malformations such as anencephaly occur in 1 per 175 births in Ireland compared with 1 per 2700 births in Uganda. Birth defects seem to be higher in Negroid than in Caucasian infants, possibly due to malnutrition and some practices of pregnant Negroid women [10].

The present study was carried out to assess the frequency of congenital malformations in Port Harcourt in Rivers state, an oil production area of Nigeria. There is no formal documentation of congenital anomalies in this part of $\mathrm{Ni}$ geria, which is an oil production area. These data will serve as part of the sta- tistics for this part of the South-South geopolitical zone of Nigeria.

\section{Methods}

This was a records-based retrospective, descriptive study. The records of congenital malformation in the maternity sections of the departments of obstetrics and gynaecology and paediatrics of the University of Port Harcourt teaching hospital and Braithwaite Memorial hospital in Rivers State were studied. Birth records and lists of congenital malformations were compiled over a 14-year period from 1990 to 2003. Congenital anomalies were arranged according to systems of the body. The incidence of congenital anomalies was calculated per 1000 births and as percentages of anomalies.

\section{Results}

The type of anomaly and the incidence in each body system are presented in Tables 1 and 2. The records showed that University of Port Harcourt teaching hospital had a total of 19572 births with $78(0.4 \%)$ congenitally malformed babies. The body systems most affected were the central nervous system in $46.2 \%$ of cases (an incidence of $1.84 / 1000$ births), skeletal system in $43.6 \%$ (1.74/1000 births), urogenital system in $5.1 \%(0.20 / 1000$ births $)$, respiratory system in $2.6 \%(0.10 / 1000$ births) and gastrointestinal tract in $2.6 \%$ (0.10/1000 births)

Braithwaite Memorial hospital recorded 20121 births with 47 (0.2\%) congenital malformed babies. Malformations involved the central nervous system in $34.0 \%$ of cases $(0.80 / 1000$ births); skeletal system in $48.9 \%$ (1.14/1000 births), oral and special senses in $2.1 \%$ (0.05/1000 births), urogenital system in $6.4 \%(0.15 / 1000$ births) and gastrointestinal tract in $4.3 \%$ (0.10/1000 births).

\section{Discussion}

In this study the incidence of congenital malformation was higher in University of Port Harcourt teaching hospital than in Braithwaite Memorial hospital even though the recorded birth rate was higher in Braithwaite Memorial hospital. This may be because University of Port Harcourt teaching hospital is a tertiary specialist centre with more specialist physicians experienced in diagnosing malformations than Braithwaite Memorial hospital which is a secondary level institution. University of Port Harcourt teaching hospital may therefore be more vigilant in the diagnosis of malformations than Braithwaite Memorial hospital and may also have better record-keeping of children born with malformations.

In both hospitals the central nervous system and skeletal systems had a higher incidence of malformations compared with abnormalities related to the gastrointestinal tract and urinary systems. This is in line with the results of Ekanem et al. who reported a higher incidence of malformations in both the skeletal and central nervous systems in 2 other states of Nigeria, Akwa Ibom and Cross River [11], which are in the same geopolitical region and exposed to almost the same petrochemical hazards as Rivers state. This study also reflects previous work carried out in states within the same geopolitical region of Nigeria [12-14]. Ekanem et al., however, reported a higher incidence of malformations related to the gastrointestinal tract and urinary system in Abia State University teaching hospital located about $60 \mathrm{~km}$ from Rivers state [15]. The differences in environmental conditions may account for these differences.

It has been suggested that pollution from the petrochemical industry is a predisposing factor in some congenital malformations [16] and this requires more investigation. Port Harcourt in Rivers state is an oil-rich city in the South-South geographical zone of 


\begin{tabular}{|c|c|c|c|}
\hline System affected/type of anomaly & $\begin{array}{l}\text { No. of recorded } \\
\text { anomalies }\end{array}$ & $\begin{array}{c}\% \text { of recorded } \\
\text { anomalies } \\
(n=78)\end{array}$ & $\begin{array}{l}\text { Incidence per } \\
1000 \text { births } \\
(n=19572)\end{array}$ \\
\hline Central nervous system & 36 & 46.2 & 1.84 \\
\hline Spina bifida & 7 & 9.0 & 0.36 \\
\hline Meningocele & 2 & 2.6 & 0.10 \\
\hline Hydrocephalus & 7 & 9.0 & 0.36 \\
\hline Anencephaly & 19 & 24.4 & 0.97 \\
\hline Collapsed skull & 1 & 1.3 & 0.05 \\
\hline Skeletal system & 34 & 43.6 & 1.74 \\
\hline Talipes & 8 & 10.3 & 0.41 \\
\hline Extra digit & 12 & 15.4 & 0.61 \\
\hline Impacted shoulder & 2 & 2.6 & 0.10 \\
\hline Absence of digit & 1 & 1.3 & 0.05 \\
\hline Achondroplasia & 3 & 3.8 & 0.15 \\
\hline Amelia & 1 & 1.3 & 0.05 \\
\hline Shoulder dystocia & 4 & 5.1 & 0.20 \\
\hline Hyper-extended legs & 1 & 1.3 & 0.05 \\
\hline Urogenital system & 4 & 5.1 & 0.20 \\
\hline Ambiguous external genitalia & 1 & 1.3 & 0.05 \\
\hline Undescended testis & 2 & 2.6 & 0.10 \\
\hline Small penis & 1 & 1.3 & 0.05 \\
\hline Respiratory system & 2 & 2.6 & 0.10 \\
\hline Apnoea & 1 & 1.3 & 0.05 \\
\hline Blocked airway & 1 & 1.3 & 0.05 \\
\hline Gastrointestinal tract & 2 & 2.6 & 0.10 \\
\hline Imperforate anus & 1 & 1.3 & 0.05 \\
\hline Congenital hernia & 1 & 1.3 & 0.05 \\
\hline
\end{tabular}

Nigeria. Oil spillage from petroleum exploration affects water quality and terrestrial fauna. Gas flaring constitutes a toxicological threat to inhabitants of these areas. Heavy hydrocarbons that cannot be carried into the atmosphere fall back and become inhaled, while others get attached to vegetables for consumption, which over time may be toxic to the body or cause congenital malformations in babies born in the area. Toxic agents may have induced malformation in the fetus during the 4 th and 5th week. This period is the critical period in the formation and development of the central nervous and skeletal systems [17]. Residents in the area have reported that many pregnant women died following oil spillages. These who survived gave birth to babies with abnormal appearance. Some of these babies were ill and died, while those who survived could not attend school because they were mentally retarded or were physically challenged [18].

Inhalation of toxic gases can cause impairment of the normal development of the fetus. Environmental pollution may be responsible for the increased incidence of central nervous system malformations in Rivers state. This is supported by reports showing that increased risk of structural birth defects with chromosomal abnormalities may be caused by air pollution and proximity to hazardous waste sites $[19,20]$. There are also reports that pregnant women may have greater susceptibility to environmental toxic exposure, specifically to volatile organic compounds such as methanol, toluene and trichloroethylene [16]. Poverty, poor access to proper medical care in rural areas for pregnant women, chromosomal abnormalities and maternal age may also be factors in the occurrence of these abnormalities [21].

In the present study we did not attempt to compare the incidence of congenital abnormalities in these 2 hospitals in River state with those elsewhere, as was done by Msamati et al. in Malawi [22]. This is because of the poor record-keeping in African countries compared with developed countries where there are efficient, continuous systems of registration of congenital 


\begin{tabular}{|c|c|c|c|}
\hline System affected/type of anomaly & $\begin{array}{l}\text { No. of recorded } \\
\text { anomalies. }\end{array}$ & $\begin{array}{c}\% \text { of recorded } \\
\text { anomalies } \\
(n=47)\end{array}$ & $\begin{array}{c}\text { Incidence per } \\
1000 \text { births } \\
(n=20121)\end{array}$ \\
\hline Central nervous system & 16 & 34.0 & 0.80 \\
\hline Hydrocephalus & 6 & 12.8 & 0.30 \\
\hline Spina bifida & 3 & 6.4 & 0.15 \\
\hline Meningocele & 2 & 4.3 & 0.10 \\
\hline Anencephaly & 2 & 4.3 & 0.10 \\
\hline Microcephalus & 1 & 2.1 & 0.05 \\
\hline Down syndrome & 2 & 4.3 & 0.10 \\
\hline Skeletal system & 23 & 48.9 & 1.14 \\
\hline Talipes & 10 & 21.3 & 0.50 \\
\hline Extra digits & 6 & 12.8 & 0.30 \\
\hline Achondroplasia & 2 & 4.3 & 0.10 \\
\hline Impacted shoulder & 3 & 6.4 & 0.15 \\
\hline Cleft lip/palate & 2 & 4.3 & 0.10 \\
\hline Oral and special senses & 1 & 2.1 & 0.05 \\
\hline Congenital cataract & 1 & 2.1 & 0.05 \\
\hline Urogenital system & 3 & 6.4 & 0.15 \\
\hline Undescended testis & 2 & 4.3 & 0.10 \\
\hline Hydrocephalus & 1 & 2.1 & 0.05 \\
\hline Gastrointestinal tract & 2 & 4.3 & 0.10 \\
\hline Congenital hernia & 1 & 2.1 & 0.05 \\
\hline Imperforate anus & 1 & 2.1 & 0.05 \\
\hline
\end{tabular}

malformations [23]. Private hospitals are not required to keep records of congenital malformations and furthermore most low-income inhabitants of this city patronize traditional and spiritual birth attendants who do not keep any records of malformed babies born in their homes.
In conclusion, this study has provided some limited, baseline data on the 14-year incidence of congenital malformations in 2 public hospitals. More research is needed into long-term trends in congenital malformations and possible associations with environmental pollution in Rivers state.

\section{Acknowledgements}

We wish to thank the staff of the records section of the two hospitals, University of Port Harcourt teaching hospital and Braithwaite Memorial hospital used in this study. They were very cooperative and helped out with the data collection.

\section{References}

1. Collins P, Billets FC. The terminology of early development history, concepts and current usage. Clinical Anatomy, 1995, 8:15-48.

2. Young MW, ed. Molecular genetics of biological rhythms. New York, Marcel Decker, 1992:319.

3. Chamberlain G, Turnbull A, eds. Obstetrics, 2nd ed. London, Churchill Livingstone, 1993:103-104.

4. Harlops S, Shino PH. Alcohol, smoking and incidence of spontaneous abortion in the first trimesters. Lancet, 1980, 2:173-176.

5. Smith CG, Asch RH. Drug abuse and reproduction. Fertility and Sterility, 1987, 48:355-373.

6. Ebrahim GJ, ed. Social and community pediatrics in developing countries; caring for rural and urban poor, 2nd ed. London, Macmillan Press, 1985:110.
7. Rothlaender D, Hoppe V. Risks of non-prescription medication. Clobutinol cough syrup as a recent example. Deutsche Medizinische Wochenschrift, 2008, 133:144-146.

8. Sadler TW. Birth defects. In: Sadler TW, Langman J, eds. Langman's medical embryology, 9th ed. Philadelphia, Lippincot Williams and Wilkins, 2004:149-158.

9. Manning D et al. Unstable hip in the newborn. Irish Medical Journal, 1982, 75:463-464

10. Smith DW, ed. Recognizable patterns of human malformations. Philadelphia, WB Saunders, 1970:75-78.

11. Ekanem TB et al. Prevalence of congenital malformations in Cross River and Akwa Ibom states of Nigeria from 1980-2003. Congenital Anomalies, 2008, 48:167-170. 
12. Akinmoladun VI, Owotade FJ, Afolabi AO. Bilateral transverse facial cleft as an isolated deformity: Case report. Annals of African Medicine, 2007, 6:39-40.

13. Sunday-Adeoye I, Okonta PI, Egweuatu VE. Congenital malformations in singleton and twin births in rural Nigeria. Nigerian Postgraduate Medical Journal, 2007, 14:277-280.

14. Ugwu RO, Eneh AU, Oruamabors RS. Neural tube defects in a university teaching hospital in southern Nigeria: trends and outcome. Nigerian Journal of Medicine, 2007, 16:368-371.

15. Ekanem TB et al. Incidence of congenital malformation in the maternity section of Abia State University Teaching Hospital (ABSUTH) from 1984-1999. Journal of Experimental and Clinical Anatomy, 2004, 39:31-33.

16. Oliveira LM et al. Reproductive outcomes in an area adjacent to a petrochemical plant in southern Brazil. Revista de Saude Publica, 2002, 36(1):81-87.

17. Moore KL, Persuad TVN, eds. The developing human: Clinically oriented embryology, 7th ed. Philadelphia, WB Saunders, 2003:175,414.
18. The Niger Delta environmental survey final report. Phase 1. Abuja, Nigeria, Environmental Resources Managers Ltd, 1996.

19. Ritz B et al. Ambient air pollution and risk of birth defects in Southern California. American Journal of Epidemiology, 2002, 155:17-25.

20. Vrijheid M. Chromosomal congenital anomalies and residence near hazardous waste landfill sites. Lancet, 2007, 359:230.

21. Msamati BC, Igbigbi PS, Chisi JE. The Incidence of cleft lip, cleft palter, hydrocephalus and spina bifida at Queen Elizabeth Central Hospital, Blantyne, Malawi. Central African Journal of Medicine, 2000, 46:292-296.

22. Archibong AE et al. Congenital Malformation of the Anus and Rectum in Children in Calabar, Nigeria. Mary Slessor Journal of Medicine, 2003, 3:25-29.

23. Sipek AV, Gregor-Horacek J, Musatova D. Oblicejove rozstepy v letech 1961-2000. Vyskyt, prenatalni diagnostika a prevalence podle veku matky [Facial clefts from 1961 to 2000. Incidence, prenatal diagnosis and prevalence by maternal age]. Ceska Gynekologie, 2002, 67:260-267.

\section{World Health Assembly resolution on birth defects}

Birth defects are a significant but under-recognized cause of mortality and disability among infants and children under 5 years of age. WHO estimates that some 260000 deaths worldwide (about $7 \%$ of all neonatal deaths) were caused by congenital anomalies in 2004.

In 2010 the World Health Assembly passed resolution on birth defects (WHA63.17), which urged Member States to: i) raise awareness among about the importance of birth defects as a cause of child morbidity and mortality; ii) develop plans and activities for integrating effective interventions; iii) promote the application of internationally recognized standards regulating the use of chemical substances in the air, water and soil; iv) increase coverage of effective prevention measures including vaccination against rubella, folic acid supplementation and others; v) develop and strengthen registration and surveillance systems for birth defects in order to have accurate information available for taking decisions on prevention and control of these birth defects; vi) develop expertise and to build capacity on the prevention of birth defects and care of children with birth defects; vii) strengthen research and studies on major birth defects and promote international cooperation in combating them; viii) raise awareness about the importance of newborn screening programmes and their role in identifying infants born with congenital birth defects; ix) take all necessary measures to ensure the full enjoyment by children with disabilities of all human rights and fundamental freedoms; $\mathrm{x}$ ) and support families who have children with birth defects and associated disabilities. 